\title{
Carbonyl-phosphine hetero-ligated half-metallocene iron(II) catalysts for living radical polymerization: concomitant activity and stability
}

\author{
Muneki Ishio, Takaya Terashima, Makoto Ouchi and Mitsuo Sawamoto
}

Two neutral ligands, carbonyl (CO) and phosphine, were cooperatively incorporated into half-metallocene iron(II) complexes $\left(\mathrm{CpFeBr}(\mathrm{CO})\left(\mathrm{PR}_{3}\right) ; \mathrm{Cp}=\mathrm{C}_{5} \mathrm{H}_{5} ; \mathrm{PR}_{3}=\mathrm{PPh}_{3}, \mathrm{P}(\mathrm{OPh})_{3}, \mathrm{PMePh}_{2}, \mathrm{PMe}{ }_{2} \mathrm{Ph}, \mathrm{P}(n-\mathrm{Bu})_{3}\right)$ for more active and versatile systems in transition metal-catalyzed living radical polymerization. For methyl methacrylate (MMA) with a bromide initiator $\left[\mathrm{Me}_{2} \mathrm{C}\left(\mathrm{CO}_{2} \mathrm{Me}\right) \mathrm{CH}_{2} \mathrm{C}(\mathrm{Me})-\left(\mathrm{CO}_{2} \mathrm{Me}\right) \mathrm{Br} ; \mathrm{Me}=\mathrm{CH}_{3}\right]\left[\mathrm{H}-(\mathrm{MMA})_{2}-\mathrm{Br}\right]$, these hetero-ligated catalysts are superior, in terms of catalytic activity and molecular weight control, to similar homo-ligated half-metallocenes carrying two identical ligands such as $\mathrm{CpFeBr}(\mathrm{CO})_{2}$ and $\mathrm{CpFeBr}\left(\mathrm{PR}_{3}\right)_{2}$. Among the $\mathrm{CpFeBr}(\mathrm{CO})\left(\mathrm{PR}_{3}\right)$ complexes examined, $\mathrm{CpFeBr}(\mathrm{CO})\left(\mathrm{PMePh}_{2}\right)$ showed the highest activity and the best controllability ( $>90 \%$ conversion within $24 \mathrm{~h} ; M_{\mathrm{w}} / M_{\mathrm{n}}=1.29$ ), and the 'living' character of the polymerizations therewith was proved by sequential monomer addition experiments. In spite of the high activity, the Fe(II) complex is stable and robust enough to be handled under air, rendering it suitable for practical use. The concomitant high activity and high stability were attributed to the in situ generation of a real active catalyst with a 16-electron configuration by the irreversible release of the $\mathrm{CO}$ group from $\mathrm{CpFeBr}(\mathrm{CO})\left(\mathrm{PR}_{3}\right)$ on the activation of a terminal $\mathrm{C}-\mathrm{Br}$ bond, as confirmed by the Fourier transform infrared monitoring of model reactions with the initiator as a dormant-end model compound.

Polymer Journal (2010) 42, 17-24; doi:10.1038/pj.2009.315

Keywords: carbonyl ligand; half-metallocene; iron catalyst; living radical polymerization; metal catalysis; methacrylate; phosphine ligand

\section{INTRODUCTION}

A key component of transition metal-catalyzed chemical reactions is obviously a metal complex catalyst, which determines and controls critical parameters including rate, efficiency, selectivity, versatility and so on, ${ }^{1}$ and it is particularly true for metal-mediated living radical polymerization (Scheme 1), which we have been pursuing for over a decade (for recent reviews on transition metal catalyzed living radical polymerization, see Kamigaito et al., ${ }^{2,3}$ Ouchi et al. ${ }^{4}$ and Matyjaszewski and $\mathrm{Xja}^{5}$ ). In general, a metal complex consists of a transition metal center and ligands, and the two components are connected through coordination and sometimes through metal-carbon bonds formed from a vacant $d$-orbital of the former and $\sigma$-, $\pi$ - or $n$-electrons of the latter. The ligands thereby affect the electronic as well as steric environments of complexes and, in turn, their catalytic performance.

Living radical polymerizations are now powerful tools to synthesize controlled polymeric architectures, because, unlike the ionic counterparts, they are simple and easy to execute, robust and reproducible under varying conditions, and, above all, versatile and applicable to a wide range of monomers including functional derivatives that are often required in biochemistry, materials science and other disciplines beyond chemistry. 'Transition metal-catalyzed' living radical polymerization (Scheme 1) is one of several such systems in which metal catalysts are responsible not only for mediating initiation and propagation but also for molecular weight control, reaction rate and the range of applicable monomers, among other factors. ${ }^{2-5}$

For example, a catalyst $\left(\mathrm{Mt}^{\mathrm{n}} ; n=\right.$ valence number $)$ activates the carbon-halogen bond in an initiator (I-X) or in a dormant polymer terminal $(\sim \mathrm{C}-\mathrm{X})$ so as to trigger its homolysis into a carboncentered growth-active radical $\left(\mathrm{I}^{\bullet}\right.$ or $\sim \mathrm{C}^{\bullet}$ ) by one-electron oxidation from $\mathrm{Mt}^{\mathrm{n}}$ to $\mathrm{Mt}^{\mathrm{n}+1}$. These growing species propagate with monomers, and the oxidized catalyst sooner or later donates back its halogen $\mathrm{X}$ to the radical, to regenerate the dormant terminal while returning to the original lower valence state by one-electron reduction from $\mathrm{Mt}^{\mathrm{n}+1}$ to $\mathrm{Mt}^{\mathrm{n}}$. The polymerization thus proceeds by repeating the reversible activation-deactivation process or a oneelectron oxidation-reduction cycle, and with the dormant species thermodynamically much more favored than the radical species, the instantaneous radical concentration is kept so low as to practically suppress undesirable bimolecular terminations and chain-transfer reactions. 
For such a unique catalysis, ruthenium ${ }^{6,7}$ and $\operatorname{copper}^{8}$ catalysts are vanguards, and their catalytic activities are high enough to induce not only living homopolymerizations but also block and random copolymerizations of virtually all radically polymerizable monomers.

Belonging to the group- 8 family as with ruthenium, divalent iron $\left(\mathrm{Fe}^{\mathrm{II}}\right)$ also potentially catalyzes living radical polymerization, and since the first successful example with $\mathrm{FeCl}_{2}\left(\mathrm{PPh}_{3}\right)_{2},{ }^{9}$ a fairly wide variety of iron catalysts have been developed with the use of different ligands, including bipyridine, ${ }^{10}$ cyclopentadiene $(\mathrm{Cp}),{ }^{11}$ pentamethylcyclopentadiene, ${ }^{12}$ isophthalic acid, ${ }^{13}$ imidazolidene, ${ }^{14}$ diimine,${ }^{15}$ diiminopyridine, ${ }^{16}$ salicylaldiminato, ${ }^{17}$ pyridylphosphine, ${ }^{18}$ triazacyclononane, ${ }^{19}$ alkyl phosphine, ${ }^{20}$ bis(oxazoline), ${ }^{21}$ phosphine-nitrogen chelates $^{22}$ and phosphazene. ${ }^{23}$ The increasingly extensive development primarily stems from the additional advantages of iron complexes: environmentally benign, safe (or less toxic), biocompatible and abundant. ${ }^{24}$ Nevertheless, in general, iron catalysts are inferior to ruthenium and copper counterparts, especially in terms of versatility in monomers, fine reaction tuning and tolerance of polar functionality and solvents. Therefore, improvement in iron catalysts is of importance and would promise actual applications of metal-catalyzed living radical polymerization.

This work was thus to design and develop novel iron complexes that are more active and versatile in living radical polymerization or, more specifically, a series of saturated (18-electron) cyclopentadienyl (Cp) $\mathrm{Fe}^{\mathrm{II}}$ bromides with two neutral ligands $\left(\mathrm{L}^{1}\right.$ and $\left.\mathrm{L}^{2}\right)$ : $\mathrm{Fe}^{\mathrm{II}} \mathrm{Br}(\mathrm{Cp}) \mathrm{L}^{1} \mathrm{~L}^{2}$. As proposed for similar 18-electron ruthenium complexes (for example, (Ind) $\mathrm{RuCl}\left(\mathrm{PPh}_{3}\right)_{2}{ }^{25}$ and $\mathrm{Cp}^{\star} \mathrm{RuCl}\left(\mathrm{PPh}_{3}\right)_{2} ;{ }^{26}$ Ind $=\mathrm{C}_{9} \mathrm{H}_{7}$; $\mathrm{Cp}^{*}=\mathrm{C}_{5} \mathrm{Me}_{5}$ ), they would turn 'unsaturated' in the activation process on acquiring a halogen from an initiator or a dormant polymer terminal by ligand release or by slipping from $\eta^{5}$ to $\eta^{3}$ configurations. Thus, the combination of two neutral ligands in $\mathrm{Fe}^{\mathrm{II}} \mathrm{Br}(\mathrm{Cp}) \mathrm{L}^{1} \mathrm{~L}^{2}$ would be important for the smooth conversion to the unsaturated form on one-electron oxidation as well as for the one-electron reduction of the central iron in the reverse step.

Herein, we targeted 'hetero-ligated' complexes, namely, introduction of two different neutral ligands onto the $\mathrm{Fe}^{\mathrm{II}}$ center, such as triphenyl(alkyl)phosphine $\left(\mathrm{PR}_{3}\right)$ and carbonyl (CO) to construct $\mathrm{Fe}^{\mathrm{II}} \mathrm{Br}(\mathrm{Cp})(\mathrm{CO})\left(\mathrm{PR}_{3}\right)$. In general, the former ligand is a ' $\sigma$-donor'

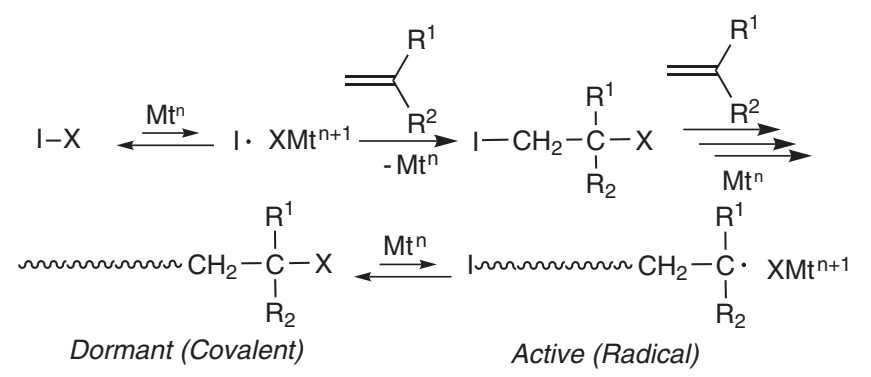

Scheme 1 Transition metal-catalyzed living radical polymerization. to increase the electron density of the central metal, whereas the latter is a ' $\pi$-acceptor' to reduce the electron density by coordination through back donation. Such a hetero ligation would be prospective for the facile and fast structural conversion of catalysts from their saturated to unsaturated forms by cooperative adjustment of the electronic states. $\mathrm{Fe}{ }^{\mathrm{II}} \mathrm{Br}(\mathrm{Cp})(\mathrm{CO})\left(\mathrm{PR}_{3}\right)$ can be easily prepared by the reaction of commercially available $\mathrm{Fe}^{\mathrm{II}} \mathrm{Br}(\mathrm{Cp})(\mathrm{CO})_{2}$ with $\mathrm{PR}_{3}$ on heating (Scheme 2), ${ }^{27}$ and thus a variety of phosphines with different properties would allow both electric and steric modulations of the iron complexes into more active, versatile and functionality tolerant catalysts. This work uses these catalysts for living radical polymerization of methyl methacrylate (MMA). Also, the catalytic activity and the reaction mechanism were examined by cyclic voltammetry $(\mathrm{CV})$ and Fourier transform infrared (FT-IR).

\section{EXPERIMENTAL PROCEDURE}

\section{Materials}

Methyl methacrylate (TCI; purity $>99 \%$ ) and methyl acrylate (TCI; purity $>99 \%$ ) were dried overnight over calcium chloride and purified by double distillation from calcium hydride before use. 2-Hydroxyethyl methacrylate (HEMA) (Aldrich, St Louis, MO, USA; purity >99\%) was distilled under reduced pressure before use. Poly(ethyleneglycol) methacrylate (PEGMA; $\mathrm{CH}_{2}=\mathrm{CMeCO}_{2}\left(\mathrm{CH}_{2} \mathrm{CH}_{2} \mathrm{O}\right)_{n} \mathrm{Me} ; \mathrm{Me}=\mathrm{CH}_{3} ; n=8.5$ on average) (Aldrich) and $N, N^{\prime}$-dimethylaminoethyl methacrylate (DMAEMA) (TCI; purity $>98 \%$ ) were purified by being passed through an inhibitor removal column (Aldrich) and were subsequently degassed by three-time vacuum-argon bubbling cycles before use. The MMA dimer bromide [H-(MMA $)_{2}-\mathrm{Br} ; \mathrm{H}-\left(\mathrm{CH}_{2} \mathrm{CMeCO}_{2} \mathrm{Me}\right)_{2}-\mathrm{Br}$ ] as an initiator was prepared according to the literature. ${ }^{28,29} \mathrm{Cp}_{2} \mathrm{Fe}_{2}(\mathrm{CO})_{4}$ (Aldrich; purity $>99 \%$ ) was used as received and handled in a glove box (MBraun Labmaster 130, M. Braun Inertgas-Systeme GmbH, Garching, Germany) under a moisture- and oxygen-free argon atmosphere $\left(\mathrm{H}_{2} \mathrm{O}<\right.$ 1 p.p.m.; $\mathrm{O}_{2}<1$ p.p.m.). Triphenylphosphine $\left(\mathrm{PPh}_{3} ; \mathrm{Ph}=\mathrm{C}_{6} \mathrm{H}_{5}\right)$ (Aldrich, purity $>99 \%)$, methyldiphenylphosphine $\left(\mathrm{PMePh}_{2}\right)$ (Aldrich; purity $\left.>99 \%\right)$, dimethylphenylphosphine $\left(\mathrm{PMe}_{2} \mathrm{Ph}\right)$ (Aldrich; purity $\left.>97 \%\right)$, tributylphosphine $\left[\mathrm{P}(n-\mathrm{Bu})_{3}\right]$ (Aldrich; purity $\left.>97 \%\right)$, and triphenylphosphite $\left[\mathrm{P}(\mathrm{OPh})_{3}\right]$ (Aldrich; purity $>97 \%$ ) were used as received. Toluene, dichloromethane $\left(\mathrm{CH}_{2} \mathrm{Cl}_{2}\right)$ and $n$-hexane (all Kishida Kagaku, Osaka, Japan; purity $>99 \%$ ) were dried and purified by passing through purification columns (Solvent Dispensing System, SG Water USA, Nashua, NH, USA; Glass Contour) and bubbled with dry nitrogen for more than $15 \mathrm{~min}$ immediately before use. Chloroform $\left(\mathrm{CHCl}_{3}\right)$ (Wako Chemicals, Osaka, Japan; anhydrous; purity $>99 \%$ ) was bubbled with dry nitrogen for more than $15 \mathrm{~min}$ immediately before use. $n$-Octane (internal standard for gas chromatography) and 1,2,3,4tetrahydronaphthalene (tetralin; internal standard for ${ }^{1} \mathrm{H}$ NMR) were dried over calcium chloride and distilled twice from calcium hydride.

\section{Iron complexes}

$\mathrm{CpFeBr}(\mathrm{CO})_{2}$ was prepared by the method of Fischer and $\mathrm{Moser}^{30}$ and Hallam and Pauson. ${ }^{31} \mathrm{IR}\left(\mathrm{CHCl}_{3}\right): 2053,2007 \mathrm{~cm}^{-1} v(\mathrm{CO})$. Anal. calcd for $\mathrm{C}_{7} \mathrm{H}_{5} \mathrm{BrFeO}_{2}$ : C, 32.73; H, 1.96; Br, 31.11. Found: C, 33.17; H, 2.07; Br, 30.83. $\mathrm{CpFeBr}\left(\mathrm{PMePh}_{2}\right)_{2}$ was obtained by the method of Lehmkuhl and Mehler. ${ }^{32}$

A series of $\mathrm{CpFeBr}(\mathrm{CO})\left(\mathrm{PR}_{3}\right)$ were synthesized by the method of Treichel et al. as follows: ${ }^{27}$ A toluene solution of $\mathrm{CpFeBr}(\mathrm{CO})_{2}(1.0 \mathrm{~g}, 3.89 \mathrm{mmol})$ and

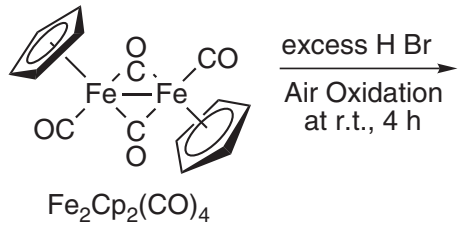

$\mathrm{CpFeBr}(\mathrm{CO})_{2}$

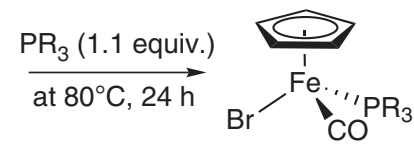

$\mathrm{CpFeBr}(\mathrm{CO})\left(\mathrm{PR}_{3}\right)$

$\left[\mathrm{PR}_{3}: \mathrm{P}(\mathrm{OPh})_{3}, \mathrm{PPh}_{3}, \mathrm{PMePh}_{2}\right.$,

Scheme 2 Syntheses of $\mathrm{CpFeBr}(\mathrm{CO})\left(\mathrm{PR}_{3}\right)$. 
1.1 equivalent of $\mathrm{PR}_{3}\left[\mathrm{PPh}_{3}, \mathrm{P}(\mathrm{OPh})_{3}, \mathrm{PMePh}_{2}, \mathrm{PMe}_{2} \mathrm{Ph}\right.$ or $\left.\mathrm{P}(n-\mathrm{Bu})_{3}\right]$ was magnetically stirred at $80^{\circ} \mathrm{C}$ for $24 \mathrm{~h}$ under dry argon. The solutions gradually changed from rust to yellow-green irrespective of $\mathrm{PR}_{3}$ being used. The reaction mixture was then filtered at $25^{\circ} \mathrm{C}$ to remove precipitates, and the filtrate was evaporated in vacuo to dryness to remove the solvent. The crude product was washed with $n$-hexane $(15 \mathrm{ml} \times 3)$, dissolved in $\mathrm{CH}_{2} \mathrm{Cl}_{2}(8.0 \mathrm{ml})$ and recrystallized by the gradual addition of $n$-hexane $(40 \mathrm{ml})$, followed by standing at $-30^{\circ} \mathrm{C}$ for $72 \mathrm{~h}$. The supernatant solvent was removed by a cannula with filter paper, and the crystal was washed with $n$-hexane $(2.0 \mathrm{ml} \times 2)$ and dried under vacuum. The complexes were characterized by elemental analysis and $500-\mathrm{MHz}{ }^{1} \mathrm{H}-\mathrm{NMR}$ spectroscopy at room temperature in $\mathrm{CDCl}_{3}$ on a Jeol JNM-ECA500 spectrometer (Jeol, Tokyo, Japan).

$\mathrm{CpFeBr}(\mathrm{CO})\left(\mathrm{PPh}_{3}\right)$ : isolated yield, 14\%. ${ }^{1} \mathrm{H}-\mathrm{NMR}$ (p.p.m.): 4.39 (s, 5H, Cp$H)$, 7.3-7.5 (m, 15H, Ar-H). IR $\left(\mathrm{CHCl}_{3}\right): 1963 \mathrm{~cm}^{-1} v(\mathrm{CO})$. Anal. calcd for $\mathrm{C}_{24} \mathrm{H}_{20} \mathrm{BrFeOP}: \mathrm{C}, 58.69 ; \mathrm{H}, 4.10 ; \mathrm{Br}, 16.27$. Found: $\mathrm{C}, 58.51 ; \mathrm{H}, 4.07 ; \mathrm{Br}, 16.49$.

$\mathrm{CpFeBr}(\mathrm{CO})\left[\mathrm{P}(\mathrm{OPh})_{3}\right]$ : isolated yield, $86 \% .{ }^{1} \mathrm{H}-\mathrm{NMR}$ (p.p.m.): 4.17 (s, $5 \mathrm{H}$, Cp-H), $7.15(\mathrm{~m}, 2 \mathrm{H}, \mathrm{Ar}-\mathrm{H}), 7.38(\mathrm{~m}, 12 \mathrm{H}, \mathrm{Ar}-\mathrm{H})$. IR $\left(\mathrm{CHCl}_{3}\right): 1989 \mathrm{~cm}^{-1}$ $v(\mathrm{CO})$. Anal. calcd for $\mathrm{C}_{24} \mathrm{H}_{20} \mathrm{BrFeO}_{4} \mathrm{P}: \mathrm{C}, 53.47 ; \mathrm{H}, 3.74 ; \mathrm{Br}, 14.82$. Found: C, 53.39; $\mathrm{H}, 3.80 ; \mathrm{Br}, 14.58$.

$\mathrm{CpFeBr}(\mathrm{CO})\left(\mathrm{PMePh}_{2}\right)$ : isolated yield, 32\%. ${ }^{1} \mathrm{H}-\mathrm{NMR}$ (p.p.m.): 2.04 (d, 3H, P-CH $\left.{ }_{3}\right), 4.44$ (s, 5H, Cp-H), 7.4-7.5 (m, 8H, Ar-H), 7.75-7.80 (m, 2H, Ar-H). IR $\left(\mathrm{CHCl}_{3}\right): 1959 \mathrm{~cm}^{-1} v(\mathrm{CO})$. Anal. calcd for $\mathrm{C}_{19} \mathrm{H}_{18} \mathrm{BrFeOP}$ : C, 53.19; $\mathrm{H}$, 4.23; Br, 18.62. Found: C, 53.63; H, 4.42; Br, 17.39.

$\mathrm{CpFeBr}(\mathrm{CO})\left(\mathrm{PMe}_{2} \mathrm{Ph}\right.$ ): isolated yield, $20 \%{ }^{1} \mathrm{H}-\mathrm{NMR}$ (p.p.m.): 1.68 (d, $3 \mathrm{H}$, P- $\left.\mathrm{CH}_{3}\right), 2.06$ (d, 3H, P-CH $), 4.38$ (s, 5H, Cp- $\left.H\right), 7.45$ (m, 3H, Ar- $\left.H\right), 7.69$ $(\mathrm{t}, 2 \mathrm{H}, \mathrm{Ar}-\mathrm{H})$. IR $\left(\mathrm{CHCl}_{3}\right): 1956 \mathrm{~cm}^{-1} v(\mathrm{CO})$. Anal. calcd for $\mathrm{C}_{14} \mathrm{H}_{16} \mathrm{BrFeOP}$ : C, 45.82; H, 4.39; Br, 21.77. Found: C, 46.35; H, 4.50; Br, 19.79 .

$\mathrm{CpFeBr}(\mathrm{CO})\left[\mathrm{P}(n-\mathrm{Bu})_{3}\right]$ : isolated yield, $43 \% .{ }^{1} \mathrm{H}-\mathrm{NMR}$ (p.p.m.): $0.86(\mathrm{t}, 9 \mathrm{H}$, $\left.\mathrm{CH}_{3}\right), 1.3-1.4\left(\mathrm{~m}, 12 \mathrm{H}, \mathrm{CH}_{2}\right), 1.7-1.8\left(\mathrm{q}, 6 \mathrm{H}, \mathrm{P}-\mathrm{CH}_{2}\right), 4.47$ (s, 5H, Cp-H). IR $\left(\mathrm{CHCl}_{3}\right): 1954 \mathrm{~cm}^{-1} v(\mathrm{CO})$. Anal. calcd for $\mathrm{C}_{18} \mathrm{H}_{32} \mathrm{BrFeOP}$ : C, 50.14; H, 7.48; $\mathrm{Br}, 18.53$. Found: $\mathrm{C}, 50.07 ; \mathrm{H}, 7.64 ; \mathrm{Br}, 18.35$.

\section{Polymerization procedures}

Polymerization was carried out by the syringe technique under dry argon in baked glass tubes equipped with a three-way stopcock or in sealed glass vials. A typical procedure for MMA polymerization with $\mathrm{H}-(\mathrm{MMA})_{2}-\mathrm{Br} / \mathrm{CpFeBr}$ (CO) $\left(\mathrm{PMePh}_{2}\right)$ was as follows: in a 50 -ml round-bottom flask were sequentially added $\mathrm{CpFeBr}(\mathrm{CO})\left(\mathrm{PMePh}_{2}\right)(21.5 \mathrm{mg}, 0.05 \mathrm{mmol})$, toluene $(2.23 \mathrm{ml}), n$-octane $(0.27 \mathrm{ml})$, MMA $(2.14 \mathrm{ml}, 20 \mathrm{mmol})$, and $\mathrm{H}-(\mathrm{MMA})_{2}-\mathrm{Br}(0.36 \mathrm{ml}$ of $553.4 \mathrm{~mm}$ in toluene, $0.20 \mathrm{mmol}$ ) under dry argon at room temperature, where the total volume of the reaction mixture was thus $5.0 \mathrm{ml}$. Immediately after mixing, aliquots $(0.80 \mathrm{ml}$ each $)$ of the solution were injected into glass tubes, which were then sealed (except when a stopcock was used) and placed in an oil bath kept at the desired temperature. In predetermined intervals, the polymerization was terminated by cooling the reaction mixtures to $-78^{\circ} \mathrm{C}$. Monomer conversion was determined from the concentration of residual monomer measured by gas chromatography with $n$-octane as an internal standard. The quenched reaction solutions were diluted with toluene $(\sim 20 \mathrm{ml})$, washed with water three times, and evaporated to dryness to give the products that were subsequently dried overnight under vacuum at room temperature.

For PEGMA, DMAEMA and HEMA, the same procedures as described above were applied, except that monomer conversion was determined by ${ }^{1} \mathrm{H}$ NMR from the integrated peak area of the olefinic protons of the monomers with tetralin as the internal standard. The products were similarly isolated but without washing with water because of their hydrophilicity.

\section{Model reactions}

Model reactions between the iron complex catalysts and $\mathrm{H}-(\mathrm{MMA})_{2}-\mathrm{Br}$ as a dormant-end model were followed under an inert atmosphere by FT-IR spectroscopy with a JASCO FT/IR 4200 spectrometer. (Jasco, Tokyo, Japan) Typical procedures were as described below for $\mathrm{CpFeBr}(\mathrm{CO})\left(\mathrm{PMePh}_{2}\right)$ : The iron complex $\left(2.1 \mathrm{mg}, 5.0 \times 10^{-3} \mathrm{mmol}\right), \mathrm{H}-(\mathrm{MMA})_{2}-\mathrm{Br}\left(5.6 \mathrm{mg}, 2.0 \times 10^{-2} \mathrm{mmol}\right)$ and toluene $(1.0 \mathrm{ml})$ were added under dry argon into a baked glass tube equipped with a three-way stopcock. The mixture was stirred at $60^{\circ} \mathrm{C}$ for $8 \mathrm{~h}$, and the solvent was removed by evaporation. The residue was dissolved in degassed $\mathrm{CHCl}_{3}$ $(1.0 \mathrm{ml})$, and the solution was transferred under dry argon into a sealed liquid $\mathrm{KBr}$ cell (optical path, $0.1 \mathrm{~mm}$ ). Spectra were recorded at predetermined intervals.

\section{Measurements}

For poly(MMA) and poly(methyl acrylate), $M_{\mathrm{n}}$ and $M_{\mathrm{w}} / M_{\mathrm{n}}$ were measured by size-exclusion chromatography in chloroform at $40^{\circ} \mathrm{C}$ on three polystyrene-gel columns (Shodex K-805 L, Shodex, Tokyo, Japan (pore size: 20-1000 A; $8.0 \mathrm{~mm}$ i.d. $\times 30 \mathrm{~cm}$ ); flow rate, $1.0 \mathrm{ml} \mathrm{min}^{-1}$ ) connected to a Jasco PU-980 precision pump and a Jasco 930-RI refractive-index detector, and a Jasco 970-UV ultraviolet detector. The columns were calibrated against 13 standard poly(MMA) samples (Polymer Laboratories, Church Stretton, UK; $M_{\mathrm{n}}=630-1200000$, $\left.M_{\mathrm{w}} / M_{\mathrm{n}}=1.06-1.22\right)$ as well as the monomer. For poly(PEGMA), poly(DMAEMA) and poly(HEMA), DMF containing $10 \mathrm{~mm} \mathrm{LiBr}$ was applied as an eluent.

Cyclic voltammograms were recorded on a Hokuto Denko HZ-3000 apparatus (Hokuto Denko, Tokyo, Japan). A typical procedure is as follows: $\mathrm{CpFeBr}(\mathrm{CO})\left(\mathrm{PMePh}_{2}\right)(15.0 \mathrm{mg}, 0.035 \mathrm{mmol})$ was dissolved into a $100 \mathrm{~mm}$ solution of $n-\mathrm{Bu}_{4} \mathrm{NPF}_{6}$ (supporting electrolyte) in $\mathrm{CH}_{2} \mathrm{ClCH}_{2} \mathrm{Cl}(7.0 \mathrm{ml})$ under dry argon in a baked glass tube equipped with a three-way stopcock.
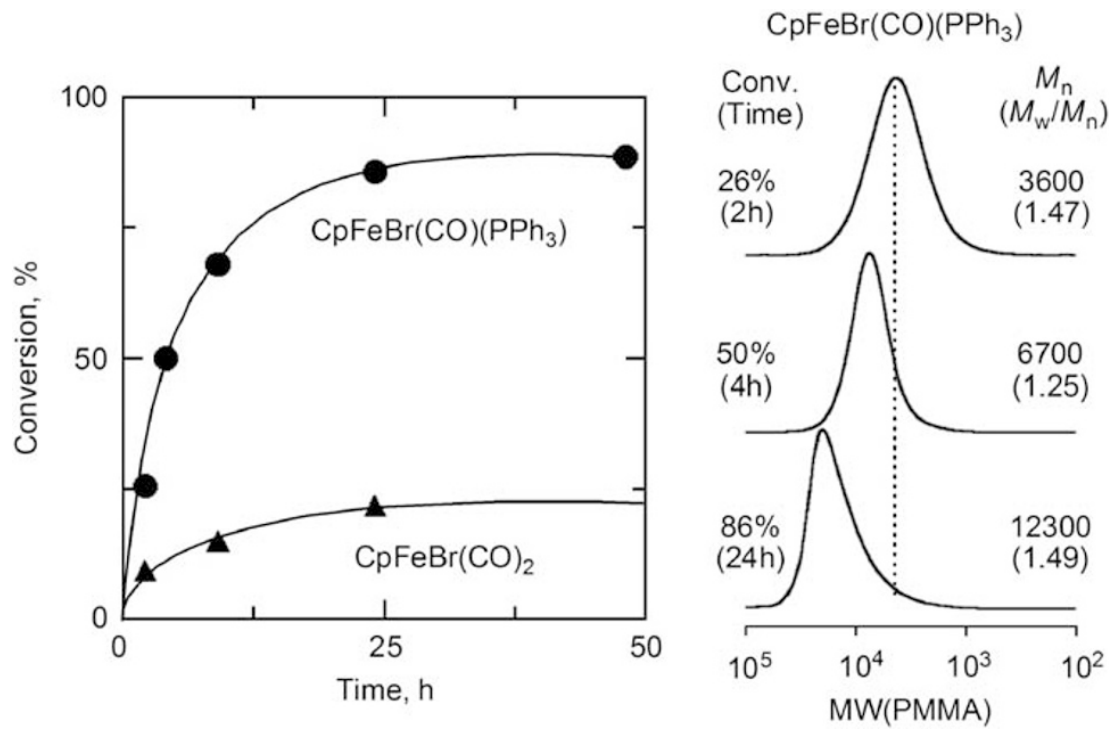

Figure 1 Living radical polymerization of methyl methacrylate $(\mathrm{MMA})$ with $\mathrm{H}-(\mathrm{MMA})_{2}-\mathrm{Br} / \mathrm{Fe}(\mathrm{II})$ catalyst in toluene at $60^{\circ} \mathrm{C}$ : $[\mathrm{MMA}]_{0}=4000 \mathrm{mM}$; $\left[\mathrm{H}-(\mathrm{MMA})_{2}-\right.$ $\mathrm{Br}]_{0}=40 \mathrm{~mm} ;[\mathrm{Fe}(\mathrm{II}) \text { catalyst }]_{0}=10 \mathrm{~mm}$. Fe(II) catalyst: $\mathrm{CpFeBr}(\mathrm{CO})\left(\mathrm{PPh}_{3}\right)(\bullet), \mathrm{CpFeBr}(\mathrm{CO})_{2}(\mathbf{\Lambda})$. 

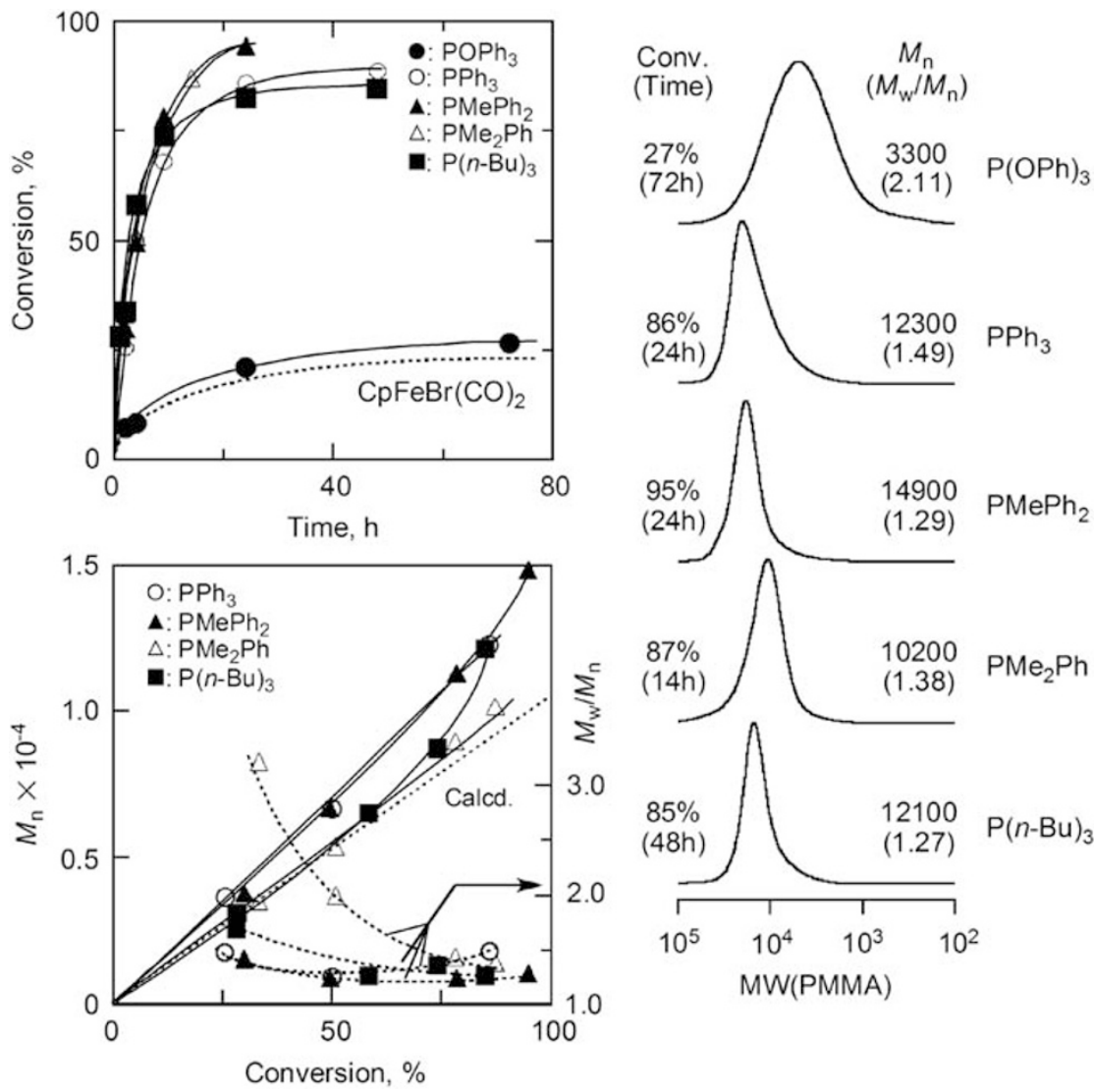

Figure 2 Effects of phosphine ligand on living radical polymerization of methyl methacrylate (MMA) with $\left.\mathrm{H}-(\mathrm{MMA})_{2}-\mathrm{Br} / \mathrm{CpFeBr}(\mathrm{CO})(\mathrm{PR})_{3}\right)$ in toluene at $60{ }^{\circ} \mathrm{C}$ : $[\mathrm{MMA}]_{0}=4000 \mathrm{~mm} ;\left[\mathrm{H}-(\mathrm{MMA})_{2}-\mathrm{Br}\right]_{0}=40 \mathrm{~mm} ;\left[\mathrm{CpFeBr}(\mathrm{CO})\left(\mathrm{PR}_{3}\right)\right]_{0}=10 \mathrm{~mm} . \mathrm{PR}_{3}: \mathrm{P}(\mathrm{OPh})_{3}$

$(\bullet), \mathrm{PPh}_{3}(\mathrm{O}), \mathrm{PMePh}_{2}(\mathbf{\Delta}), \mathrm{PMe}_{2} \mathrm{Ph}(\Delta), \mathrm{P}(n-\mathrm{Bu})_{3}(\boldsymbol{\square})$.

Voltammograms were recorded under argon at a scan rate of $0.1 \mathrm{Vs}^{-1}$ in a three-electrode cell equipped with a platinum disk as a working electrode, a platinum wire as a counter electrode and an $\mathrm{Ag} / \mathrm{AgCl}$ electrode as a reference.

\section{RESULTS AND DISCUSSION}

Living radical polymerization of MMA with $\mathrm{CpFeBr}(\mathrm{CO})\left(\mathrm{PPh}_{3}\right)$ An FeCp complex with triphenylphosphine $\left(\mathrm{PPh}_{3}\right)$ and $\mathrm{CO}[\mathrm{CpFeBr}$ (CO) $\left(\mathrm{PPh}_{3}\right)$ ] was used as our first 'hetero-ligated' catalyst for polymerization of MMA in conjunction with $\mathrm{H}-(\mathrm{MMA})_{2}-\mathrm{Br}$ as an initiator without an additive in toluene at $60{ }^{\circ} \mathrm{C}\left([\mathrm{MMA}]_{0} /\left[\mathrm{H}-(\mathrm{MMA})_{2}-\mathrm{Br}\right]_{0} /\right.$ $\left.\left[\mathrm{CpFeBr}(\mathrm{CO})\left(\mathrm{PPh}_{3}\right)\right]=4000 / 40 / 10 \mathrm{~mm}\right)$. As shown in Figure 1 , the catalyst induced a smooth polymerization (conversion 90\% in $24 \mathrm{~h}$ ) and gave controlled PMMAs with fairly narrow molecular weight distributions (MWDs; $M_{\mathrm{w}} / M_{\mathrm{n}}<1.5$ ). On the other hand, a homoligated dicarbonyl derivative $\left(\mathrm{CpFeBr}(\mathrm{CO})_{2}\right.$; precursor of $\mathrm{CpFeBr}$ $\left.(\mathrm{CO})\left(\mathrm{PPh}_{3}\right)\right)$ resulted in limited conversion $(\sim 20 \%)$ and broader MWDs $\left(M_{\mathrm{w}} / M_{\mathrm{n}}>2.0\right)$. These results indicate that the design of neutral ligands for $\mathrm{Fe}^{\mathrm{II}} \mathrm{Br}(\mathrm{Cp}) \mathrm{L}^{1} \mathrm{~L}^{2}$ is critical to the catalytic activity and that such a hetero ligation is promising for living radical polymerization.

Effects of phosphine ligands in $\mathrm{CpFeBr}(\mathrm{CO})\left(\mathrm{PR}_{3}\right)$

Given the possibility of living radical polymerization with $\mathrm{CpFeBr}$ $(\mathrm{CO})\left(\mathrm{PPh}_{3}\right)$, we prepared a series of $\mathrm{Cp}$-based iron catalysts carrying different phosphines $\left(\mathrm{CpFeBr}(\mathrm{CO})\left(\mathrm{PR}_{3}\right) ; \mathrm{PR}_{3}=\mathrm{P}(\mathrm{OPh})_{3}, \mathrm{PMePh}_{2}\right.$, $\left.\mathrm{PMe}_{2} \mathrm{Ph}, \mathrm{P}(n-\mathrm{Bu})_{3}\right)$ to study the effects of the phosphine ligand in MMA polymerization with $\mathrm{H}-(\mathrm{MMA})_{2}-\mathrm{Br}$ in toluene at $60^{\circ} \mathrm{C}$

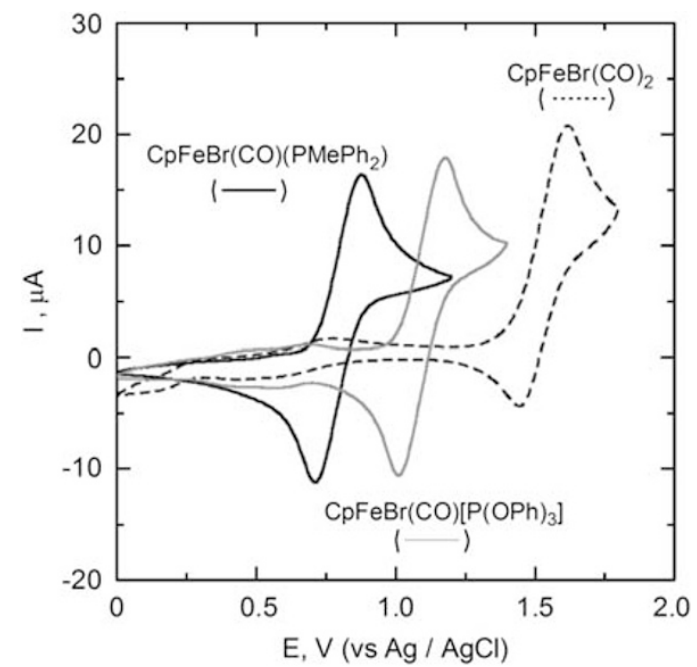

Figure 3 Cyclic voltammograms of $\mathrm{Fe}(\mathrm{II})$ catalysts in $\mathrm{ClCH}_{2} \mathrm{CH}_{2} \mathrm{Cl}$ at $25^{\circ} \mathrm{C}$ : $[\mathrm{Fe}(\mathrm{II}) \text { catalyst }]_{0}=5.0 \mathrm{~mm},\left[n-\mathrm{Bu}_{4} \mathrm{NPF}_{6}\right]_{0}=100 \mathrm{~mm}$. Fe(II) catalyst: $\mathrm{CpFeBr}$ (CO) $\left(\mathrm{PMePh}_{2}\right.$ ) (solid line); $\mathrm{CpFeBr}(\mathrm{CO})\left[\mathrm{P}(\mathrm{OPh})_{3}\right]$ (gray line); $\mathrm{CpFeBr}(\mathrm{CO})_{2}$ (dashed line).

(Figure 2). The phosphite complex $\left[\mathrm{PR}_{3}=\mathrm{P}(\mathrm{OPh})_{3}\right]$ resulted in lower activity, similar to the dicarbonyl complex $\left[\mathrm{CpFeBr}(\mathrm{CO})_{2}\right]$, whereas the other four complexes catalyzed smooth and faster polymerizations to give $>80 \%$ conversion within $24 \mathrm{~h}$. On near completion of the reactions they gave almost controlled polymers 
$\left(M_{\mathrm{w}} / M_{\mathrm{n}}=1.25-1.50\right)$; however, an endurance of the catalytic activity was dependent on the ligands: polymerization was gradually retarded at $\sim 75 \%$ conversion with $\mathrm{PPh}_{3}$ and $\mathrm{P}(n-\mathrm{Bu})_{3}$, whereas such retardation was absent with $\mathrm{PMePh}_{2}$ and $\mathrm{PMe}_{2} \mathrm{Ph}$. Also, MWDs $\left(M_{\mathrm{w}} / M_{\mathrm{n}}\right.$ values $)$ stayed rather unchanged throughout the polymerizations, but with $\mathrm{PMe}_{2} \mathrm{Ph}, \mathrm{MWD}$ drastically decreased from an initial broad distribution (conversion=33\%, $M_{\mathrm{w}} / M_{\mathrm{n}}>3$; conversion $=87 \%, M_{\mathrm{w}} / M_{\mathrm{n}}=1.38$ ). These differences of the phosphine ligands in catalytic performance were analytically examined in the following sections.

\section{Cyclic voltammetry analysis}

As catalysis in metal-catalyzed living radical polymerization is based on a one-electron redox cycle of the catalyst, $\mathrm{CV}$ is helpful to discuss catalytic activities. Thus, CV was run with the iron complexes to

Table 1 Cyclic voltammetry analyses of $\mathrm{CpFeBr}(\mathrm{CO}) \mathrm{L}$ catalysts ${ }^{\mathrm{a}}$

\begin{tabular}{lcccc}
\hline Ligand & $\mathrm{E}_{p a}(V)$ & $\mathrm{E}_{p c}(V)$ & $\mathrm{E}_{1 / 2}(V)$ & $\Delta \mathrm{E}(V)$ \\
\hline $\mathrm{CO}$ & 1.63 & 1.44 & 1.54 & 0.18 \\
$\mathrm{P}(\mathrm{OPh})_{3}$ & 1.18 & 1.01 & 1.09 & 0.17 \\
$\mathrm{PPh}_{3}$ & 0.90 & 0.72 & 0.81 & 0.18 \\
$\mathrm{PMePh}_{2}$ & 0.88 & 0.71 & 0.79 & 0.17 \\
$\mathrm{PMe}_{2} \mathrm{Ph}$ & 0.84 & 0.66 & 0.75 & 0.18 \\
$\mathrm{P}(n-\mathrm{Bu})_{3}$ & 0.80 & 0.61 & 0.71 & 0.19 \\
\hline
\end{tabular}

$\mathrm{a}[\mathrm{CpFeBr}(\mathrm{CO}) \mathrm{L}]_{0}=5.0 \mathrm{~mm},\left[n-\mathrm{Bu}_{4} \mathrm{NPF}_{6}\right]_{0}=100 \mathrm{~mm}$ in $\mathrm{CH}_{2} \mathrm{ClCH}_{2} \mathrm{Cl}$ at $25^{\circ} \mathrm{C}$. $E_{1 / 2}=\left(E_{\mathrm{pa}}+E_{\mathrm{pc}}\right) / 2, \Delta E=E_{\mathrm{pa}}-E_{\mathrm{pc}}$. determine and compare redox potentials: $E_{\mathrm{pa}}$, oxidation peak; $E_{\mathrm{pc}}$, reduction peak; $E_{1 / 2}=\left(E_{\mathrm{pa}}+E_{\mathrm{pc}}\right) / 2 ; \Delta E=E_{\mathrm{pa}}-E_{\mathrm{pc}}$.

All the complexes showed clear and reversible oxidation/reduction waves in the range of 0 to $1.8 \mathrm{~V}$, most likely assigned to one-electron redox cycle between $\mathrm{Fe}^{\mathrm{II}}$ and $\mathrm{Fe}^{\mathrm{III}}$, and the waves were reproducible in several scans without hysteresis (Figure 3 and Table 1). This indicates the high stability of both oxidized and reduced states, in contrast to a homo-ligated dicarbonyl iodide complex $\left[\mathrm{CpFeI}(\mathrm{CO})_{2}\right]$, which requires a certain metal alkoxide $\left[\mathrm{Ti}(\mathrm{O} i-\mathrm{Pr})_{4}\right.$ or $\left.\mathrm{Al}(\mathrm{O} i-\mathrm{Pr})_{3}\right]$ as an additive (cocatalyst) for such a recurrent cycle as well as for catalyzing living radical polymerizations. ${ }^{12,33}$

In addition to ligating mode (homo vs hetero), the redox potential was obviously dependent on the nature of the ligands: the dicarbonyl $(\mathrm{CO} / \mathrm{CO})$ and the phosphite $\left[\mathrm{CO} / \mathrm{P}(\mathrm{OPh})_{3}\right]$ complexes had higher redox potentials and hence low catalytic activities. In these complexes, electron donation from the ligands to iron would be insufficient for facilitating the oxidation process. The other complexes, all active in MMA polymerization, in fact showed lower potentials. Beside these qualitative assessment, no quantitative correlation between $E$-value and catalytic performance was identified for the four $\mathrm{Fe}^{\mathrm{II}} \mathrm{Br}(\mathrm{Cp}) \mathrm{L}^{1} \mathrm{~L}^{2}$ catalysts.

\section{FT-IR analysis: conversion to $16 \mathrm{e}$ complex}

The CO ligand on $\mathrm{Fe}^{\mathrm{II}} \mathrm{Br}(\mathrm{Cp})(\mathrm{CO})\left(\mathrm{PR}_{3}\right)$ was analyzed by FT-IR, to see the possible structural conversion of the saturated $18 \mathrm{e}$ complex into a $16 \mathrm{e}$ form, when it reacted with an initiator $\left[\mathrm{H}-(\mathrm{MMA})_{2}-\mathrm{Br}\right]$ at polymerization temperature $\left(60^{\circ} \mathrm{C}\right)$ (see Experimental procedure section).
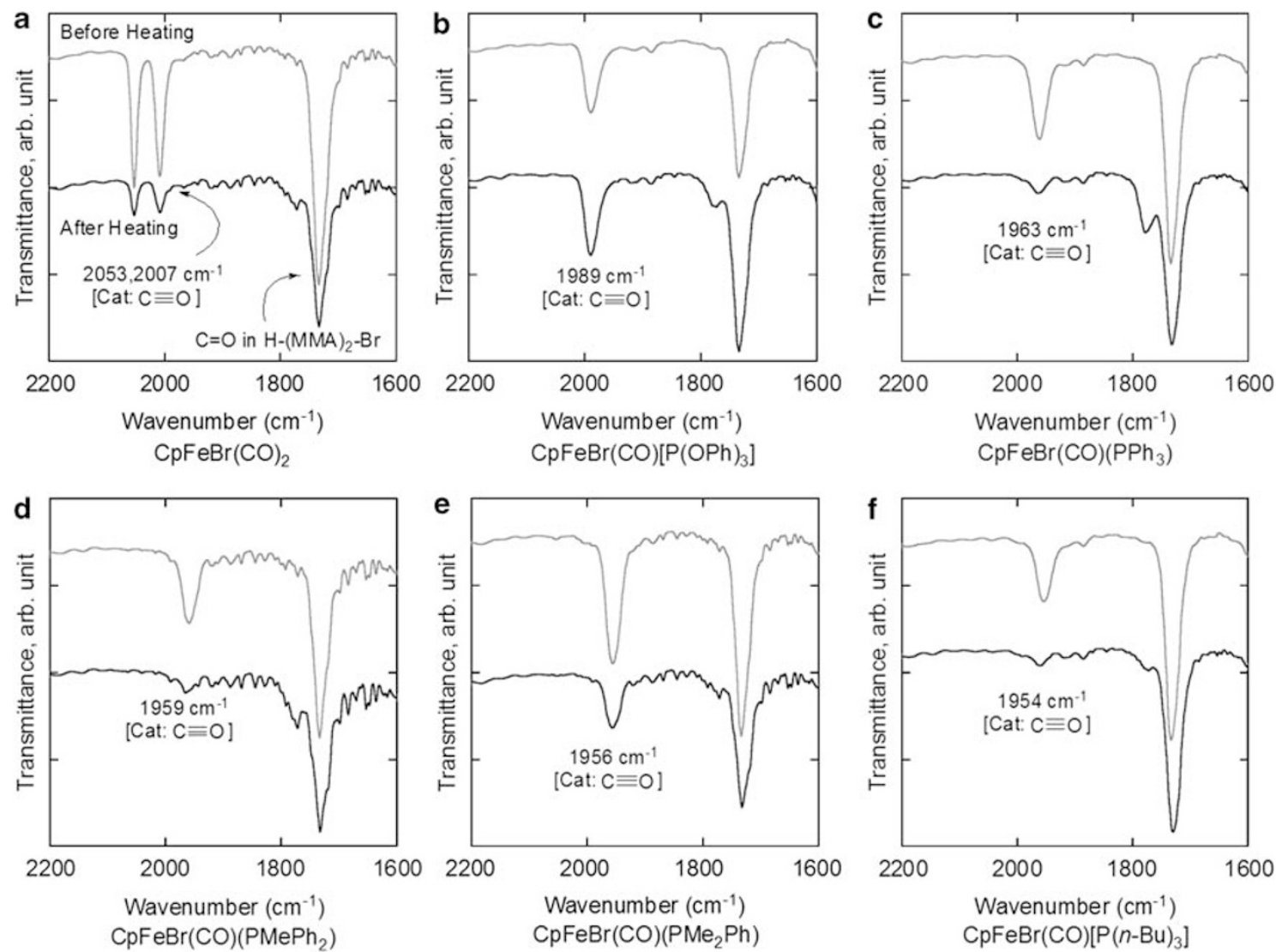

Figure 4 IR Analysis of $\mathrm{Fe}(\mathrm{II})$ complex/H-(MMA) $)_{2}-\mathrm{Br}$ in $\mathrm{CHCl}_{3}$ at $25^{\circ} \mathrm{C}$ : $[\mathrm{Fe}(\mathrm{II}) \text { complex }]_{0}=5.0 \mathrm{~mm}$; $\left[\mathrm{H}-(\mathrm{MMA})_{2}-\mathrm{Br}\right]_{0}=20 \mathrm{~mm}$. Condition: 'before heating' (gray line); 'after heating,' aged at $60^{\circ} \mathrm{C}$ for $8 \mathrm{~h}$ before measurement (solid line). $\mathrm{Fe}(\mathrm{II})$ catalyst: (a) $\mathrm{CpFeBr}(\mathrm{CO})_{2} ;(\mathbf{b}) \mathrm{CpFeBr}(\mathrm{CO})\left[\mathrm{P}(\mathrm{OPh})_{3}\right]$; (c) $\mathrm{CpFeBr}(\mathrm{CO})$ $(\mathrm{PPh})_{3} ;(\mathbf{d}) \mathrm{CpFeBr}(\mathrm{CO}) \mathrm{PMePh}_{2} ;(\mathbf{e}) \mathrm{CpFeBr}(\mathrm{CO}) \mathrm{PMe}_{2} \mathrm{Ph}$; (f) $\mathrm{CpFeBr}(\mathrm{CO})\left[\mathrm{P}(n-\mathrm{Bu})_{3}\right]$. 


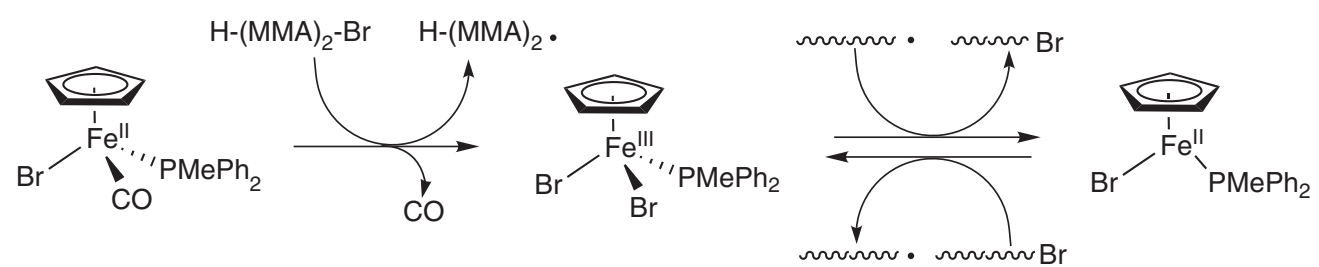

Scheme 3 Proposed polymerization mechanism.
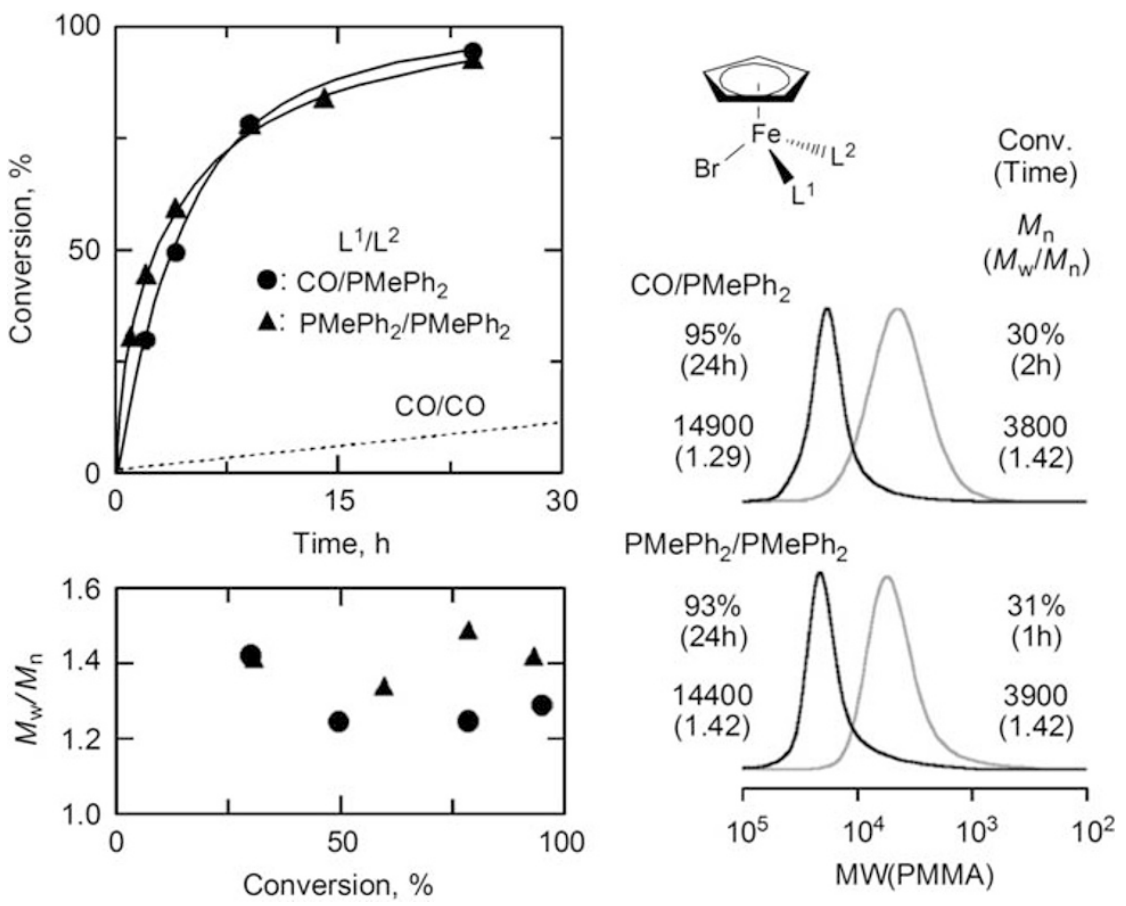

Figure 5 Living radical polymerization of MMA with $\mathrm{H}-(\mathrm{MMA})_{2}-\mathrm{Br} / \mathrm{Fe}(\mathrm{II})$ catalyst in toluene at $60^{\circ} \mathrm{C}$ : $[\mathrm{MMA}]_{0}=4000 \mathrm{mM} ;\left[\mathrm{H}-(\mathrm{MMA})_{2}-\mathrm{Br}\right]_{0}=40 \mathrm{mM} ;[\mathrm{Fe}(\mathrm{II})$

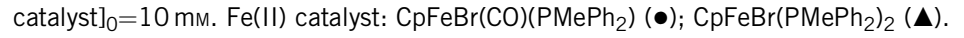

Figure 4 shows IR spectra from 1600 to $2200 \mathrm{~cm}^{-1}$ for the mixture with $\mathrm{CpFeBr}(\mathrm{CO})_{2}$ (Figure 4a) and $\mathrm{CpFeBr}(\mathrm{CO})\left(\mathrm{PR}_{3}\right)\left(\mathrm{PR}_{3}=\right.$ $\mathrm{P}(\mathrm{OPh})_{3}, \mathrm{PPh}_{3}, \mathrm{PMePh}_{2}, \mathrm{PMe}_{2} \mathrm{Ph}, \mathrm{P}(n-\mathrm{Bu})_{3}$; Figures $\left.4 \mathrm{~b}-\mathrm{f}\right)$. The IR data consist of two spectra for each complex, where the upper spectrum is for 'before heating' and the lower spectrum for 'after heating.' Peaks at around $2000 \mathrm{~cm}^{-1}$ are derived from the $\mathrm{C} \equiv \mathrm{O}$ stretching and those around $1730 \mathrm{~cm}^{-1}$ are due to the ester $\mathrm{C}=\mathrm{O}$ in the initiator. With less active catalysts, $\mathrm{CpFeBr}(\mathrm{CO})_{2}$ and $\mathrm{CpFeBr}(\mathrm{CO})$ $\left[\mathrm{P}(\mathrm{OPh})_{3}\right]$, the $\mathrm{C} \equiv \mathrm{O}$ bands remained unchanged even after the heating, indicating that the CO ligands were still ligated on the complexes (Figures $4 \mathrm{a}$ and $\mathrm{b}$ ). In contrast, with the active catalysts $\left[\mathrm{CpFeBr}(\mathrm{CO})\left(\mathrm{PR}_{3}\right) ; \quad \mathrm{PR}_{3}=\mathrm{PPh}_{3}, \quad \mathrm{PMePh}_{2}, \mathrm{PMe}_{2} \mathrm{Ph}, \mathrm{P}(n-\mathrm{Bu})_{3}\right]$, the same $\mathrm{C} \equiv \mathrm{O}$ bands almost disappeared or weakened more (Figures $4 \mathrm{c}-\mathrm{f}$ ), which suggests that the CO ligand was irreversibly released on activation of the initiator. Indeed, when allowed to stand for analysis, the solution changed from green (18e complex) to reddish brown (16e complex); the color change thus supports CO elimination.

These results show that a more electron-donating phosphine such as $\mathrm{P}(n-\mathrm{Bu})_{3}$ promotes the $\mathrm{CO}$ elimination to give in situ an active unsaturated 16e-complex. However, with $\mathrm{PMe}_{2} \mathrm{Ph}$, the elimination seemed slower, as judged from the clearly remaining peak, even after heating. The slow CO release would account for the initial broad MWD with $\mathrm{PMe}_{2} \mathrm{Ph}$ (Figure 2). Thus, CO elimination is essential to catalyze living radical polymerization, and it is affected by the neighboring phosphine ligand.
Scheme 3 shows a proposed mechanism based on these analyses. $\mathrm{CO}$ release should be irreversible because of the gaseous character of $\mathrm{CO}$, and hence the polymerization involves $16 \mathrm{e}$ and $17 \mathrm{e}$ complexes, 16e $\mathrm{Fe}$ (II) for the activation of dormant species and 17e Fe(III) for radical deactivation (capping).

$\mathrm{CpFeBr}(\mathrm{CO})\left(\mathrm{PMePh}_{2}\right)$ vs $\mathrm{CpFeBr}\left(\mathrm{PMePh}_{2}\right)_{2}$

According to the proposed mechanism, the catalytic properties of $\mathrm{CpFeBr}(\mathrm{CO})\left(\mathrm{PR}_{3}\right)$ might be similar to those of the corresponding diphosphine analogs $\left[\mathrm{CpFeBr}\left(\mathrm{PR}_{3}\right)_{2}\right]$. Thus, with $\mathrm{PMePh}_{2}$, its catalysis in MMA polymerization was examined to clarify some superiority of the hetero ligation (Figure 5).

Complex $\mathrm{CpFeBr}\left(\mathrm{PMePh}_{2}\right)_{2}$ induced MMA polymerization at almost the same rate as with the carbonyl-phosphine complex $\left[\mathrm{CpFeBr}(\mathrm{CO})\left(\mathrm{PMePh}_{2}\right)\right]$ and gave controlled polymers. The sizeexclusion chromatography curves of the products were fairly narrow, but a slight 'tailing' in the lower molecular weight region was noticeable, and hence the $M_{\mathrm{w}} / M_{\mathrm{n}}$ values are a little larger. For diphosphine complexes, a released phosphine (non-volatile) remains in the system and might have a chance to re-coordinate the iron, in contrast to the irreversible elimination of the $\mathrm{CO}$ ligand in $\mathrm{CpFeBr}(\mathrm{CO})\left(\mathrm{PMePh}_{2}\right)$. Such a phosphine re-coordination might make the dormant-active species equilibrium slower, resulting in broader MWDs.

The CO-phosphine complexes were stable enough to be treated under air. For example, a solution of $\mathrm{CpFeBr}(\mathrm{CO})\left(\mathrm{PMePh}_{2}\right)$ in 

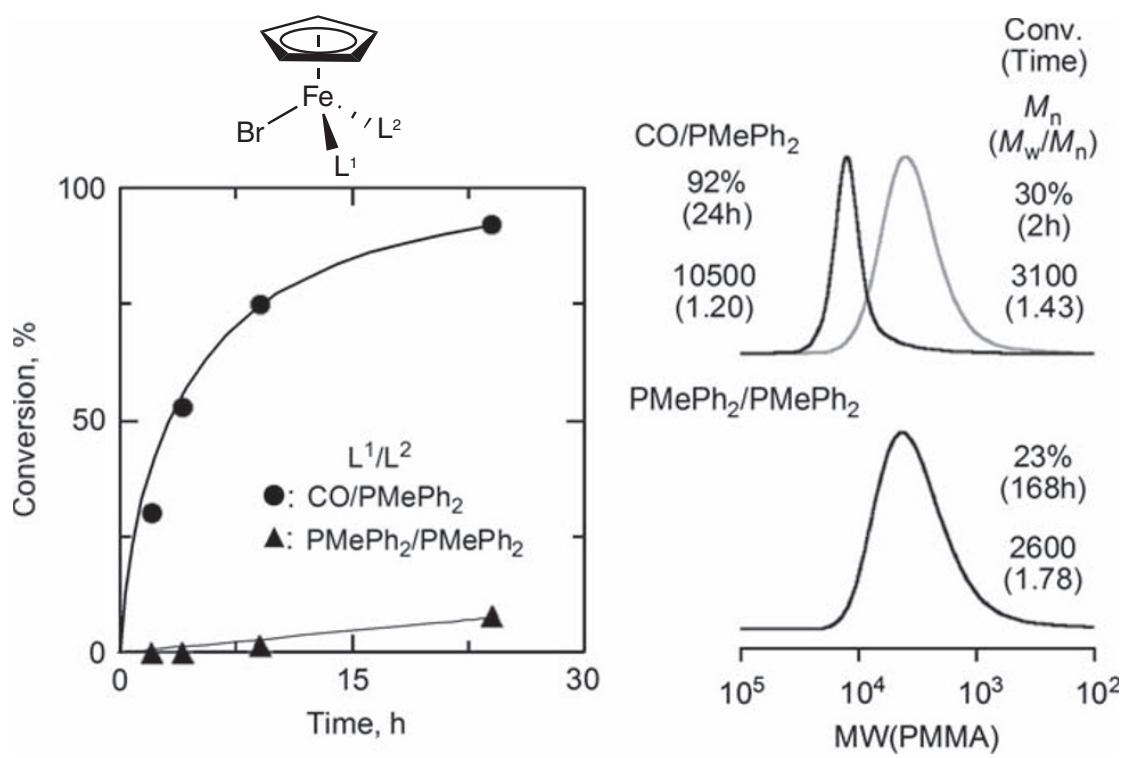

Figure 6 Living radical polymerization of MMA in toluene at $60^{\circ} \mathrm{C}$ with $\mathrm{H}-(\mathrm{MMA})_{2}-\mathrm{Br} / \mathrm{Fe}(\mathrm{II})$ catalyst, followed by air bubbling to the catalyst at $25^{\circ} \mathrm{C}$ for $3 \mathrm{~min}:[\mathrm{MMA}]_{0}=4000 \mathrm{~mm}$; $\left[\mathrm{H}-(\mathrm{MMA})_{2}-\mathrm{Br}\right]_{0}=40 \mathrm{~mm}$; $[\mathrm{Fe}(\mathrm{II}) \text { catalyst }]_{0}=10 \mathrm{~mm}$. Fe(II) catalyst: $\mathrm{CpFeBr}(\mathrm{CO})\left(\mathrm{PMePh}_{2}\right)(\bullet) ; \mathrm{CpFeBr}(\mathrm{PMePh})_{2}(\boldsymbol{\Lambda})$.
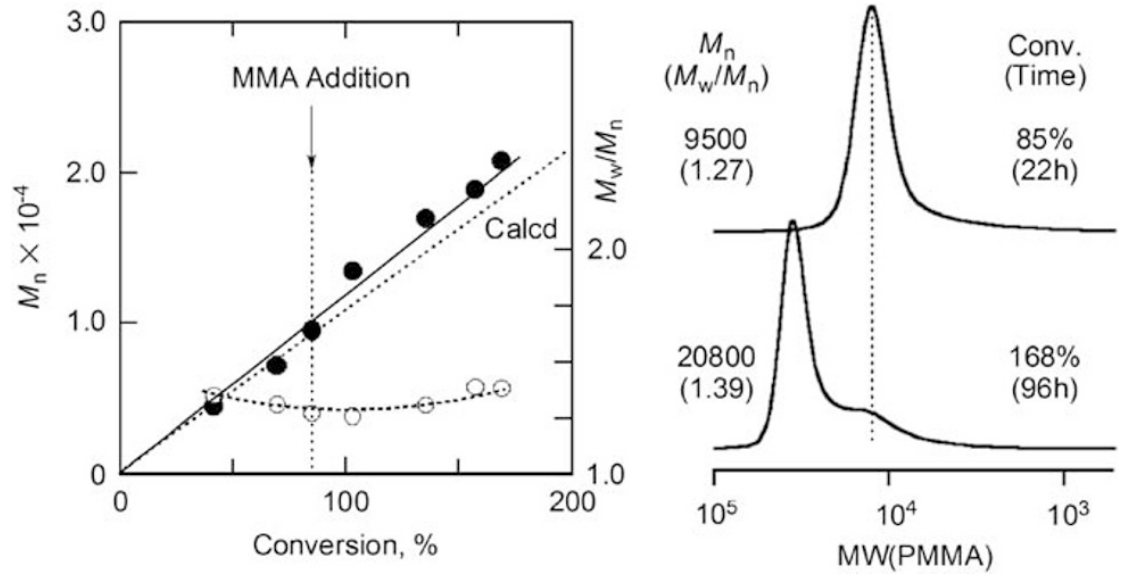

Figure 7 Monomer addition experiment in the polymerization of methyl methacrylate $(\mathrm{MMA})$ with $\mathrm{H}-(\mathrm{MMA})_{2}-\mathrm{Br} / \mathrm{CpFeBr}(\mathrm{CO})\left(\mathrm{PMePh}_{2}\right)$ in toluene at $60{ }^{\circ} \mathrm{C}$ : $[\mathrm{MMA}]_{0}=[\mathrm{MMA}]_{\mathrm{add}}=4000 \mathrm{~mm} ;\left[\mathrm{H}-(\mathrm{MMA})_{2}-\mathrm{Br}\right]_{0}=40 \mathrm{~mm} ;\left[\mathrm{CpFeBr}(\mathrm{CO})\left(\mathrm{PMePh}_{2}\right)\right]_{0}=10 \mathrm{~mm}$.

toluene was deliberately bubbled with air for $3 \mathrm{~min}$ before polymerization. The green color of the complex was not changed throughout the procedures, indicating some tolerance of the air. After degassing, the catalyst solution was directly used for MMA polymerization under the same conditions as mentioned above (Figure 6). Even after the air exposure, the iron catalyst turned out as active as an oxygen-free complex. In sharp contrast, the diphosphine complex $\mathrm{CpFeBr}$ $\left(\mathrm{PMePh}_{2}\right)_{2}$, similarly exposed to air before use, immediately changed in color, from purple into brown, and an unidentified insoluble complex precipitated. Air exposure also deteriorated catalytic activity and controllability. Thus, the hetero-ligated complexes were tolerant of air and superior in handling to the diphosphine homo-ligated counterparts.

\section{Sequential monomer addition}

To investigate the living nature of the MMA polymerization with $\mathrm{CpFeBr}(\mathrm{CO})\left(\mathrm{PMePh}_{2}\right)$, a monomer addition experiment was performed (Figure 7). A fresh MMA was added to the polymerization solution when MMA conversion reached over $80 \%$ in $\sim 22 \mathrm{~h}$. Mono- mer consumption was smooth in the second stage and gave an additional $83 \%$ conversion (totally 168\%). Polymer molecular weight was linearly increased even at the second stage, and the size-exclusion chromatography curves shifted to a higher molecular weight while keeping the MWD narrow, although just a small peak was left. As a concurrent addition of the catalyst was not required in the second stage, the complex, or its modified active form, retains catalytic activity during the two-step polymerization.

\section{Polymerization of other monomers}

Most of the conventional iron complexes such as $\mathrm{FeBr}_{2}\left(\mathrm{PPh}_{3}\right)_{2}$ tend to be deactivated on interaction with polar groups (for example, amino and hydroxy groups) as well as with polar solvents. However, the dicarbonyl $\mathrm{Cp}$ iron complexes $\left[\mathrm{CpFeBr}(\mathrm{CO})_{2}\right]$ and the related analogs are tolerant enough to catalyze living radical polymerizations of styrene and acrylates even in the presence of a large amount of water. ${ }^{34}$ Such backgrounds encouraged us to use $\mathrm{CpFeBr}(\mathrm{CO})$ $\left(\mathrm{PMePh}_{2}\right)$ for various polar monomers: methacrylate with a pendent poly(ethyleneglycol) (PEGMA); DMAEMA; HEMA; and methyl 
Table 2 Polymerizations of various monomers with $\mathrm{CpFeBr}(\mathrm{CO})\left(\mathrm{PMePh}_{2}\right)$

\begin{tabular}{lcccc}
\hline Monomer & Time $(h)$ & Conversion (\%) & $M_{\mathrm{n}}$ & $M_{\mathrm{w}} / M_{\mathrm{n}}$ \\
\hline PEGMA $^{\mathrm{a}}$ & 4 & 35 & 20500 & 1.45 \\
PEGMA $^{\mathrm{a}}$ & 24 & 69 & 31400 & 1.51 \\
DMAEMA $^{\mathrm{b}}$ & 24 & 73 & 26000 & 2.90 \\
HEMA $^{c}$ & 168 & 51 & 98200 & 2.59 \\
MA $^{\mathrm{d}}$ & 168 & 73 & 6200 & 2.70
\end{tabular}

${ }^{a}[\mathrm{PEGMA}]_{0}=500 \mathrm{~mm},[\mathrm{H}-(\mathrm{MMA})-\mathrm{Br}]_{0}=5.0 \mathrm{~mm},\left[\mathrm{CpFeBr}(\mathrm{CO})\left(\mathrm{PMePh}_{2}\right)\right]_{0}=5.0 \mathrm{~mm}$ in toluene at $60^{\circ} \mathrm{C}$

${ }^{\mathrm{b}}[\mathrm{DMAEMA}]_{0}=2000 \mathrm{~mm},[\mathrm{H}-(\mathrm{MMA})-\mathrm{Br}]_{0}=20 \mathrm{~mm},\left[\mathrm{CpFeBr}(\mathrm{CO})\left(\mathrm{PMePh}_{2}\right)\right]_{0}=10 \mathrm{~mm}$ in toluene at $60^{\circ} \mathrm{C}$

${ }^{c}[\mathrm{HEMA}]_{0}=2000 \mathrm{~mm},[\mathrm{H}-(\mathrm{MMA})-\mathrm{Br}]_{0}=20 \mathrm{~mm},\left[\mathrm{CpFeBr}(\mathrm{CO})\left(\mathrm{PMePh}_{2}\right)\right]_{0}=10 \mathrm{~mm}$ in methanol at $60^{\circ} \mathrm{C}$

${ }^{d}[M A]_{0}=4000 \mathrm{~mm},[\mathrm{H}-(\mathrm{MMA})-\mathrm{Br}]_{0}=40 \mathrm{~mm},\left[\mathrm{CpFeBr}(\mathrm{CO})\left(\mathrm{PMePh}_{2}\right)\right]_{0}=10 \mathrm{~mm}$ in toluene at $80^{\circ} \mathrm{C}$.

acrylate (Table 2). The polymerization of PEGMA was fairly controlled, in which the molecular weights were increased with conversion, but it was decelerated at around 70\% conversion. For the other monomers, polymerization control was totally difficult, as suggested by varying colors of polymerization solutions (yellow (PEGMA, DMAEMA and methyl acrylate) or white (HEMA)), which were totally different from reddish brown in the living MMA polymerization. As prepared solutions of $\mathrm{CpFeBr}(\mathrm{CO})\left(\mathrm{PMePh}_{2}\right)$ with these polar monomers, on the other hand, were colored green, as with the catayst/ MMA solution, implying that not the 18e complex but the in situ generated $16 \mathrm{e}$ form $\left[\mathrm{CpFe}{ }^{\mathrm{II}} \mathrm{Br}\left(\mathrm{PMePh}_{2}\right)\right]$ or its oxidized form $\left[\mathrm{CpFe}{ }^{\mathrm{III}} \mathrm{Br}_{2}\left(\mathrm{PMePh}_{2}\right)\right]$ would be less tolerant of these monomers. Our preliminary results also indicate that electron-richer $\mathrm{Cp}^{*}$ (pentamethylcyclopentadiene) derivatives showed catalytic activity for some of these monomers, and that the Cp-based complexes such as $\mathrm{CpFeBr}(\mathrm{CO})\left(\mathrm{PMePh}_{2}\right)$ seem to be not electron-rich enough to evade poisoning by polar groups. Living radical polymerization with $\mathrm{FeCp}^{*}$ complexes will be presented in the near future.

In conclusion, a series of half-metallocene $\mathrm{Fe}(\mathrm{II})$ complexes with a $\mathrm{CO}$ and an electron-donating phosphine ligand $\left[\mathrm{CpFeBr}(\mathrm{CO})\left(\mathrm{PR}_{3}\right)\right.$; $\left.\mathrm{PR}_{3}=\mathrm{PPh}_{3}, \mathrm{PMePh}_{2}, \mathrm{PMe}_{2} \mathrm{Ph}, \mathrm{P}(n-\mathrm{Bu})_{3}\right]$ catalyzed living radical polymerization of MMA to give controlled molecular weights and narrow MWDs. Their high activities were supported by lower redox potentials with CV analysis. FT-IR analyses for reaction of the catalysts with the initiator revealed that the phosphine ligand promoted an elimination of the CO ligand in situ, to give a real active catalyst with 16e. They easily turn into active catalysts under the polymerization condition; however, they are stable enough to be treated under air. These features would be suitable for actual applications, along with the environmental aspects of a central iron.

\section{ACKNOWLEDGEMENTS}

This research was partially supported by the Ministry of Education, Science, Sports and Culture, Grant-in-Aid for Creative Scientific Research (18GS0209).

1 Crabtree, R. H. The Organometallic Chemistry of the Transition Metals (John Wiley \& Sons, Inc., New York, USA, 2001).

2 Kamigaito, M., Ando, T. \& Sawamoto, M. Metal-catalyzed living radical polymerization. Chem. Rev. 101, 3689-3745 (2001).

3 Kamigaito, M., Ando, T. \& Sawamoto, M. Metal-catalyzed living radical polymerization: discovery and developments. Chem. Rec. 4, 159-175 (2004).

4 Ouchi, M., Terashima, T. \& Sawamoto, M. Precision control of radical polymerization via transition metal catalysis: from dormant species to designed catalysts for precision functional polymers. Acc. Chem. Res. 41, 1120-1132 (2008).
5 Matyjaszewski, K. \& Xja, J. Atom transfer radical polymerization. Chem. Rev. 101, 2921-2990 (2001).

6 Kato, M., Kamigaito, M.., Sawamoto, M. \& Higashimura, T. Polymerization of Methyl Methacrylate with the Carbon Tetrachloride/Dichlorotris(triphenylphosphine)rutheniu$\mathrm{m}(\mathrm{II}) /$ Methylaluminum Bis(2,6-di-tert-butylphenoxide)Initiating System: Possibility of Living Radical Polymerization. Macromolecules 28, 1721-1723 (1995).

7 Ando, T., Kato, M., Kamigaito, M. \& Sawamoto, M. Living radical polymerization of methyl methacrylate with ruthenium complex: formation of polymers with controlled molecular weights and very narrow distributions. Macromolecules 29, 1070-1072 (1996).

8 Wang, J. S. \& Matyjaszewski, K. Controlled/'living' radical polymerization. Atom transfer radical polymerization in the presence of transition-metal complexes. J. Am. Chem. Soc. 117, 5614-5615 (1995).

9 Ando, T., Kamigaito, M. \& Sawamoto, M. Iron(II) chloride complex for living radical polymerization of methyl methacrylate. Macromolecules 30, 4507-4510 (1997).

10 Matyjaszewski, K., Wei, M., Xia, J. \& McDermott, N. E. Controlled/'Living' radical polymerization of styrene and methyl methacrylate catalyzed by iron complexes. Macromolecules 30, 8161-8164 (1997).

11 Kotani, Y., Kamigaito, M. \& Sawamoto, M. $\operatorname{FeCp}(\mathrm{CO})_{2}$ l: a phosphine-free half-metallocene-type iron(II) catalyst for living radical polymerization of styrene. Macromolecules 32, 6877-6880 (1999).

12 Kotani, Y., Kamigaito, M. \& Sawamoto, M. Living radical polymerization of styrene by half-metallocene iron carbonyl complexes. Macromolecules 33, 3543-3549 (2000).

13 Zhu, S. \& Yan, D. Atom transfer radical polymerization of methyl methacrylate catalyzed by iron" chloride/isophthalic acid system. Macromolecules 33, 8233-8238 (2000).

14 Louie, Y. \& Grubbs, R. H. Highly active iron imidazolylidene catalysts for atom transfer radical polymerization. Chem. Commun. 1479-1480 (2000).

15 Gibson, V. C., O'Reilly, R. K., Reed, W., Wass, D. F., White, A. J. P. \& Williams, D. J. Four-coordinate iron complexes bearing $\alpha$-diimine ligands: efficient catalysts for atom transfer radical polymerisation (ATRP). Chem. Commun. 1850-1851 (2002).

16 Göbelt, B. \& Matyjaszewski, K. Diimino- and diaminopyridine complexes of $\mathrm{CuBr}$ and $\mathrm{FeBr}_{2}$ as catalysts in atom transfer radical polymerization (ATRP). Macromol. Chem. Phys. 201, 1619-1624 (2000).

17 O'Reilly, R. K., Gibson, V. C., White, A. J. P. \& Williams, D. J. Design of highly active iron-based catalysts for atom transfer radical polymerization: tridentate salicylaldiminato ligands affording near ideal nernstian behavior. J. Am. Chem. Soc. 125, 84508451 (2003).

18 Xue, Z., Lee, B. W., Noh, S. K. \& Lyoo, W. S. Pyridylphosphine ligands for iron-based atom transfer radical polymerization of methyl methacrylate and styrene. Polymer $\mathbf{4 8}$, 4704-4714 (2007).

19 Niibayashi, S., Hayakawa, H., Jin, R. -H. \& Nagashima, H. Reusable and environmentally friendly ionic trinuclear iron complex catalyst for atom transfer radical polymerization. Chem. Commun. 1855-1857 (2007).

20 Uchiike, C., Terashima, T., Ouchi, M., Ando, T., Kamigaito, M. \& Sawamoto, M. Evolution of iron catalysts for effective living radical polymerization: design of phosphine/halogen ligands in $\mathrm{FeX}_{2}\left(\mathrm{PR}_{3}\right)_{2}$. Macromolecules 40, 8658-8662 (2007).

21 Ferro, R., Milione, S., Bertolasi, V., Capacchione, C. \& Grassi, A. Iron complexes of Bis(oxazoline) ligand as novel catalysts for efficient atom transfer radical polymerization of styrene. Macromolecules 40, 8544-8546 (2007).

22 Uchiike, C., Ouchi, M., Ando, T., Kamigaito, M. \& Sawamoto, M. Evolution of iron catalysts for effective living radical polymerization: $\mathrm{P}-\mathrm{N}$ chelate ligand for enhancement of catalytic performances. J. Polym. Sci., Part A: Polym. Chem. 46, 6819-6827 (2008).

23 Ishio, M. Katsube, M., Ouchi, M. Sawamoto, M. \& Inoue, Y. Active, versatile, and removable iron catalysts with phosphazenium salts for living radical polymerization of methacrylates. Macromolecules 42, 188-193 (2009).

24 Bolm, C., Legros, J., Paih, J. L. \& Zani, L. Iron-catalyzed reactions in organic synthesis. Chem. Rev. 104, 6217-6254 (2004).

25 Takahashi, H., Ando, T., Kamigaito, M. \& Sawamoto, M. Half-metallocene-type ruthenium complexes as active catalysts for living radical polymerization of methyl methacrylate and styrene. Macromolecules 32, 3820-3823 (1999).

26 Watanabe, Y., Ando, T., Kamigaito, M. \& Sawamoto, M. $\mathrm{Ru}\left(\mathrm{Cp}{ }^{\star}\right) \mathrm{Cl}\left(\mathrm{PPh}_{3}\right)_{2}$ : a versatile catalyst for living radical polymerization of methacrylates, acrylates, and styrene. Macromolecules 34, 4370-4374 (2001).

27 Treichel, P. M., Shubkin, R. L., Barnett, K. W. \& Reichard, D. Chemistry of the cyclopentadienylmetal carbonyls. II. cyclopentadienyliron carbonyl derivatives. Inorg. Chem. 5, 1177-1181 (2001).

28 Holland, K. A. \& Rae, I. D. Thermal degradation of polymers. III thermal degradation of a compound which models the head-to-head linkage in poly(methyl methacrylate). Aust. J. Chem. 40, 687-692 (1987)

29 Ando, T., Kamigaito, M. \& Sawamoto, M. Design of initiators for living radical polymerization of methyl methacrylate mediated by ruthenium(II) complex. Tetrahedron 53, 15445-15457 (1997).

30 Fischer, E. O. \& Moser, E. Inorg. Synth 12: (ed. Parry, R. W.) Ch. 2, 35-36 (Wiley, 1970).

31 Hallam, B. F. \& Pauson, P. L. Ferrocene derivatives.3. cyclopentadienyliron carbonyls. J. Chem. Soc. 3030-3037 (1956).

32 Lehmkuhl, H. \& Mehler, G. Organyleisen-komplexe des typs $\left.\mathrm{Cp}\left(\mathrm{Ph}_{2} \mathrm{P}_{\mathrm{C}} \mathrm{CH}_{2}\right]_{n} \mathrm{PPh}_{2}\right) \mathrm{Fe}-\mathrm{R}$. Chem. Ber 118, 2407-2417 (1985).

33 Ando, T., Kamigaito, M. \& Sawamoto, M. Metal alkoxides as additives for ruthenium(II)catalyzed living radical polymerization. Macromolecules 33, 6732-6737 (2000).

34 Fuji, Y., Ando, T., Kamigaito, M. \& Sawamoto, M. Iron-catalyzed suspension living radical polymerizations of acrylates and styrene in water. Macromolecules 35, 2949-2954 (2002). 